\title{
POLLUTION SOURCES AND WATER QUALITY STATE OF THE SUPRAŚL RIVER
}

\author{
Mirosław Skorbiłowicz' ${ }^{1}$, Elżbieta Skorbiłowicz ${ }^{1}$, Paulina Wójtowicz'1, \\ Piotr Ofman' ${ }^{1}$, Emilia Zamojska'
}

1 Department of Technology in Engineering and Environmental Protection, Faculty of Civil and Environmental Engineering, Bialystok University of Technology, Wiejska 45A Str., 15-351 Białystok, Poland, e-mail: m.skorbilowicz@pb.edu.pl

Received: 2015.11 .12

Accepted: 2016.03.04

Published: 2016.04.01

\begin{abstract}
The main purpose of the study was to evaluate water quality of the Supraśl river and identify its main pollution sources. On the river and its tributaries, 8 control points were selected, located near Krynica, Gródek, Nowosiółki, Zasady (mouth of the tributary Sokołda), Supraśl, Nowodworce, Dobrzyniewo (mouth of the tributary Biała) and Dzikie. The control points were selected in such a way as to take into account the impact of major point sources of analyzed components located along the river and its main tributaries on water quality in the main stream catchment. Water samples were collected once a month during the period from May to November in 2014. In water samples the concentration of dissolved oxygen, $\mathrm{Cl}^{-}, \mathrm{SO}_{4}{ }^{2-}, \mathrm{N}_{-} \mathrm{NH}_{4}{ }^{+}, \mathrm{P}_{-} \mathrm{PO}_{4}{ }^{3-}$ and the values of $\mathrm{pH}$, $\mathrm{BOD}_{5}$ and electrolytic conductivity were indicated. Based on the obtained results, loads of the individual components in river waters were calculated as a product of concentration and Supraśl waters flow rate in a particular month. Supraśl waters, due to values of most analyzed parameters, should be classified as first quality class. The source of $\mathrm{Cl}^{-}, \mathrm{SO}_{4}^{2-}, \mathrm{N}_{-} \mathrm{NH}_{4}^{+}$in Supraśl waters were treated wastewater and other anthropogenic sources associated with the basin development. Reduced Supraśl water quality is caused by the inflow of organic substances expressed by $\mathrm{BZT}_{5}$ from natural and anthropogenic origin and concentration of $\mathrm{PO}_{4}^{3-}$, which were mainly delivered with treated wastewater.
\end{abstract}

Keywords: water quality, pollution, river, wastewater.

\section{INTRODUCTION}

Water is an excellent solvent, so it can include almost all substances naturally occurring in the earth's crust and substances of anthropogenic origin [Ptoszek 2014, Skorbiłowicz and Ofman 2014]. Among all water bodies, rivers have the most heterogeneous chemical and biological composition, which is often associated with a large area occupied by their catchments [Kiryluk i Skorbiłowicz, 2005]. Over the years, there has been periodically repeated changes in the distribution of mineral component loads in surface waters. The quality of river water in catchment depends from terrain, vegetation, soil type, climatic conditions and anthropogenic pollution [Duffy and VanLoon 2008, Sojka 2009,
Bajkiewicz-Grabowska and Mikulski 2010, Ptoszek 2014]. Anthropogenic input of pollutants into the river water is caused by the proximity of villages and towns, all of which are discharging domestic and industrial wastewater and agricultural areas, which are a source of plant protection products and fertilizers [Allan 1998, Piekutin 2008, Kociołek-Balawejder and Stanisławska 2012]. Ingredients flowing with water in case of high concentrations are considered as impurities that may degrade the environment. Chemical and biological composition of water is particularly important in a situation where they are sources of drinking water. The Supraśl river is one of the drinking water sources for Białystok agglomeration and control of this water is necessary [Osmulska-Mróz et al. 1993]. 
The aim of this study was to evaluate water quality of the Supraśl river and to identify its main pollution sources.

\section{METHODS}

The Supraśl catchment covers the area of $1,844.4 \mathrm{~km}^{2}$ and is located in the central part of the region of Podlasie. It is a typical agricultural area of moderate economic growth. Supraśl is the second largest river in Podlaskie. Its total length is $93.8 \mathrm{~km}$, and the average flow is 4.18 $\mathrm{m}^{3} \cdot \mathrm{s}^{-1}$ [Skorbiłowicz 2010]. Due to the hydrographic conditions the river can be divided into three sections - upper Supraśl (93-73 km), central Supraśl (79-29 km) and lower Supraśl (29-0 $\mathrm{km})$. It begins its run near the village Topolany and heads east. By Michałowo it turns north and runs through Gródek, followed by a large part of Knyszyńska Forest. Passes Supraśl and Wasilków and in the village Złotoria falls into Narew on 299.8 kilometers of its course.

It is a typical lowland river, it is characterized by a slight decrease $(0.76 \%$ ) and lack of violent floods. Supraśl flows in the well shaped, broad valley. Forests cover $30 \%$ of the catchment area. A major role in basins plays swamps and peat bogs. Supraśl is a tortuous and meandering river, it has 18 tributaries. The first major tributary is river Słoja. It flows into the Supraśl near Nowosiółki. Above Wasilków, to Supraśl falls Sokołda - one of the biggest tributary [Program gospodarczo-ochronny... 2013]. In addition, beside Sokołda to the Płoska and Biała rivers also fall to the Supraśl - the main receiver of treated sewage from Bialystok Sewage Treatment Plant. In Wasilków, there is a surface water intake point from which water is delivered to Bialystok for domestic and industrial usage.
On the river and its tributaries, 8 control points (Figure 1) were selected, located near Krynica, Gródek, Nowosiółki, Zasady (mouth of the tributary Sokołda), Supraśl, Nowodworce, Dobrzyniewo (mouth of the tributary Biała) and Dzikie. The control points were selected in such a way as to take into account the impact of major point sources of analyzed components located along the river and its main tributaries on water quality in main stream catchment. Water samples were collected once a month during the period from May to November in 2014. The water was collected to containers made from dark glass and plastic, from the depth of about 0.5 meters.

In water samples the concentration of dissolved oxygen, $\mathrm{Cl}, \mathrm{SO}_{4}{ }^{2-}, \mathrm{N}-\mathrm{NH}_{4}^{+}, \mathrm{P}_{-} \mathrm{PO}_{4}{ }^{3-}$ and the values of $\mathrm{pH}, \mathrm{BOD}_{5}$ and electrolytic conductivity were indicated. $\mathrm{Cl}^{-}$content was determined by Mohr method. $\mathrm{SO}_{4}^{2-}, \mathrm{N}-\mathrm{NH}_{4}^{+}, \mathrm{P}_{-} \mathrm{PO}_{4}^{3-}$ were determined by the colorimetric method using a UVVIS spectrophotometer HACH DR-3900. pH, conductivity and dissolved oxygen concentration were determined by a potentiometric device. Based on the obtained results loads of the individual components in river waters were calculated as a product of concentration and the Supraśl water flow rate in a particular month. Surface water flow in the basin were obtained from the Institute of Meteorology and Water Management. At the points where flow was not indicated its values were calculated using the equation presented by Brykała [2009]:

$$
\mathrm{p}=\frac{\mathrm{Q}_{\mathrm{B}}-\mathrm{Q}_{\mathrm{A}}}{\mathrm{L}_{\mathrm{A}-\mathrm{B}}}
$$

where: $p$-river waters flow increase $\left[\mathrm{dm}^{3 \cdot} \cdot \mathrm{s}^{-1} \cdot \mathrm{km}^{-1}\right]$, $Q_{B}, Q_{A}$ - river water flow in subsequent points $\left[\mathrm{dm}^{3} \cdot \mathrm{s}^{-1}\right]$,

$L_{A-B}-$ distance between control points $[\mathrm{km}]$.

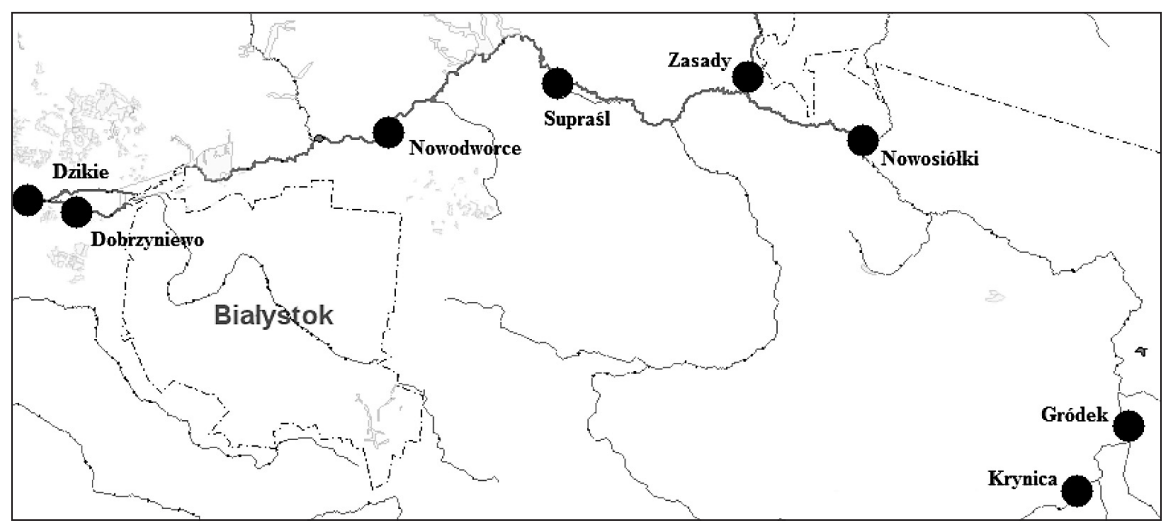

Figure 1. The measuring points on the Supraśl river [geomelio.pl] 
The scope of statistical analysis included basic measures: the arithmetic mean, median, standard deviation and extreme values of individual components. In addition, between the charges parametric Pearson correlation coefficients were calculated. Due to the heterogeneity of units in which individual variables and their values were expressed, their values have been standardized in accordance with the equation:

$$
\mathrm{x}_{\mathrm{st}}=\frac{\mathrm{x}-\overline{\mathrm{x}}}{\mathrm{OS}}
$$

where: $x_{s t}$ - variable value after standardization, $x$ - concentration of tested component, $\overline{\mathrm{X}}$ - average concentration of tested component,

$O S$ - standard deviation.

\section{RESULTS AND DISCUSSION}

$\mathrm{pH}$ of water samples ranged from 6.95 to 8.06, which shows slight variations in its value over the period of the study (Table 1). The obtained values of this indicator were characteristic for uncontaminated surface waters [Skorbiłowicz et al. 2003]. The largest $\mathrm{pH}$ value was observed in the water collected in vicinity of Zasady, and the lowest around Krynica.

The conductivity of the water was diverse, and varied in a range from 391.80 to 563.33 $\mu \mathrm{S} \cdot \mathrm{cm}^{-1}$. The highest average value of this indicator was observed in point Dzikie, and the lowest in Nowosiółki. The resulting conductiv- ity values were different from those achieved by Skorbiłowicz [2010]. The scope of this indicator, which was observed by the author in the waters of the Supraśl ranged from 220 to $1069 \mu \mathrm{S} \cdot \mathrm{cm}^{-1}$. During the study period conductivity changed regularly, as evidenced by similar values of arithmetic mean and the median, equal to 460.14 and $461.30 \mu \mathrm{S} \cdot \mathrm{cm}^{-1}$ respectively.

The average concentrations of dissolved oxygen in water did not change significantly along the Supraśl river. In each sample, the concentration of that component was not less than 7.50 $\mathrm{mg} \cdot \mathrm{dm}^{-3}$. On average, most of the dissolved oxygen was observed in Nowodworce $\left(8.57 \mathrm{mg} \cdot \mathrm{dm}^{-3}\right)$ and the least in Gródek (7.06 $\left.\mathrm{mg} \cdot \mathrm{dm}^{-3}\right)$, which may be a consequence of water self-purification [Ptoszek 2008], because organic matter degradation processes is consuming larger amounts of dissolved oxygen. Gródek is the location of a sewage treatment plant that discharges the treated wastewater to the Supraśl waters and can affect the amount of oxygen. In the area of Gródek agricultural areas are located where organic fertilization in a form of slurry is performed, which can be a source of increased organic matter amounts, getting out into Supraśl waters and reducing dissolved oxygen concentration.

$\mathrm{Cl}^{-}$concentration in water from various control points was relatively diverse and varied in a range from 5.46 to $11.87 \mathrm{mg} \cdot \mathrm{dm}^{-3}$ (Table 1 ). The smallest amounts of this indicator were observed in points Nowodworce and Nowosiółki, which were respectively equal to 5.86 and $5.46 \mathrm{mg} \cdot \mathrm{dm}^{-3}$. The highest

Table 1. Concentration summary (arithmetic mean) of tested indicators in Supraśl river waters in 2014

\begin{tabular}{|c|c|c|c|c|c|c|c|c|}
\hline \multirow{2}{*}{ Localization } & $\mathrm{pH}$ & Conductivity & $\begin{array}{l}\text { Dissolved } \\
\text { oxygene }\end{array}$ & $\mathrm{Cl}^{-}$ & $\mathrm{BZT}_{5}$ & $\mathrm{~N}-\mathrm{NH}_{4}^{+}$ & $\mathrm{SO}_{4}^{2-}$ & $\mathrm{PO}_{4}^{3-}$ \\
\hline & {$[\mathrm{pH}]$} & {$\left[\mu S \cdot \mathrm{cm}^{-1}\right]$} & {$\left[\mathrm{mg} \mathrm{O}_{2} \cdot \mathrm{dm}^{-3}\right]$} & {$\left[\mathrm{mg} \mathrm{C}^{1-\cdot} \mathrm{dm}^{-3}\right]$} & {$\left[\mathrm{mg} \mathrm{O}_{2} \cdot \mathrm{dm}^{-3}\right]$} & $\begin{array}{c}{\left[\mathrm{mg} \mathrm{NH}_{3}-\mathrm{N}\right.} \\
\left.\cdot \mathrm{dm}^{-3}\right]\end{array}$ & $\begin{array}{c}{\left[\mathrm{mg} \mathrm{SO}_{4}\right.} \\
\left.\cdot \mathrm{dm}^{-3}\right]\end{array}$ & $\begin{array}{c}{\left[\mathrm{mg} \mathrm{PO}_{4}^{3-}\right.} \\
\left.\mathrm{dm}^{-3}\right]\end{array}$ \\
\hline Krynica & $6.95-8.05$ & 502.09 & 8.10 & 1.65 & 1.35 & 0.07 & 8.24 & 0.15 \\
\hline Gródek & $6.74-8.06$ & 404.70 & 7.06 & 4.52 & 7.86 & 0.42 & 24.09 & 3.98 \\
\hline Nowosiółki & $7.16-7.68$ & 391.80 & 7.53 & 8.29 & 5.14 & 0.45 & 52.35 & 1.08 \\
\hline Zasady & $7.31-8.00$ & 474.60 & 7.66 & 21.55 & 7.57 & 0.53 & 77.15 & 1.33 \\
\hline Supraśl & $7.17-7.80$ & 448.00 & 7.54 & 40.45 & 46.95 & 1.36 & 192.26 & 3.64 \\
\hline Nowodworce & $7.20-7.86$ & 402.39 & 8.57 & 38.49 & 32.45 & 1.53 & 247.27 & 3.87 \\
\hline Dobrzyniewo & $7.25-7.94$ & 494.20 & 7.81 & 13.26 & 8.13 & 0.44 & 63.25 & 1.43 \\
\hline Dzikie & $7.15-8.01$ & 563.33 & 7.97 & 95.29 & 37.26 & 6.16 & 363.73 & 13.86 \\
\hline Arithmetic mean & - & 460.14 & 7.78 & 27.94 & 18.34 & 1.37 & 128.54 & 3.67 \\
\hline Median & - & 461.30 & 7.74 & 17.41 & 7.99 & 0.49 & 70.20 & 2.53 \\
\hline $\begin{array}{l}\text { Standard } \\
\text { deviation }\end{array}$ & - & 59.77 & 0.45 & 30.90 & 17.60 & 2.00 & 126.24 & 4.37 \\
\hline Minimum & 6.95 & 391.80 & 7.06 & 1.65 & 1.35 & 0.07 & 8.24 & 0.15 \\
\hline Maximum & 8.06 & 563.33 & 8.57 & 95.29 & 46.95 & 6.16 & 363.73 & 13.86 \\
\hline
\end{tabular}


concentration of $\mathrm{Cl}^{-}$was observed in points in the Zasady, Dzikie and Dobrzyniewo, which equaled to $10.66,10.57$ and $11.87 \mathrm{mg}^{\cdot} \mathrm{dm}^{-3}$ respectively. The points where the maximum concentration of $\mathrm{Cl}^{-}$was observed were related to sewage treatment plants occurring in catchment area. Control point Zasady, was located on the river Sokołda and $\mathrm{Cl}^{-}$ concentration could be influenced by treated wastewater from sewage treatment plant in Sokółka, while the Dzikie and Dobrzyniewo points were located downstream of the treated wastewater discharge from sewage treatment plants in Białystok. Much higher $\mathrm{Cl}^{-}$concentrations were observed by Augustyn et al. [2012] in the studies carried out in the Wisłoka. The average concentration of $\mathrm{Cl}^{-}$ observed by the authors was $18.7 \mathrm{mg}^{\cdot \mathrm{dm}^{-3}}$, with a variance in a range from 3.7 to $93.0 \mathrm{mg} \cdot \mathrm{dm}^{-3}$. The authors point out that the highest concentration of $\mathrm{Cl}^{-}$occurred in upper Wisłoka, where the discharge of mine water occurs.

The largest load of chlorides occurred in Dzikie and amounted to $95.29 \mathrm{~g} \mathrm{Cl}^{-} \cdot \mathrm{s}^{-1}$ (Table 2). Before Dzikie, the Biała estuary which flows through Bialystok receiving any excess ingredients from urbanized areas, including components originating from sewage treatment plants, falls into the Supraśl. The smallest load was obtained in waters collected from Krynica and Gródek, values of $\mathrm{Cl}^{-}$ loads were equal to 1.65 and $4.52 \mathrm{~g} \mathrm{Cl}^{-} \cdot \mathrm{s}^{-1}$. Krynica is located on semi-natural areas, which were associated with the occurrence of chlorides small loads in this part of catchment, as opposed to control point Dzikie. Chlorides have a highly conservative nature in the environment and are not transformed by migration. It can therefore be assumed that the results are highly probable and pointing the main migration routes in the Supraśl catchment. This indicator is often used to determine the migration routes of other components. The median and standard deviation values were respectively equal to 17.41 and $30.90 \mathrm{~g} \mathrm{Cl}^{-} \cdot \mathrm{s}^{-1}$. Those values show high variability in chloride loads in the Supraśl waters, which is associated with a variety of this nutrient sources within the catchment.

$\mathrm{BOD}_{5}$ values in water along the monitoring network were relatively aligned. The highest values of this indicator were in Gródek and Supra, which amounted to 11.14 and $7.71 \mathrm{mg} \cdot \mathrm{dm}^{-3}$ and the lowest in Nowosiółki and Zasady (3.14 and $3.29 \mathrm{mg} \cdot \mathrm{dm}^{-3}$ ) (Table 1). Indicated in water $\mathrm{BOD}_{5}$ values near Gródek were dependent on two wastewater treatment plants located in Gródek and the Michałowo. A similar range of this indicator was observed by
Krzemińska et al. [2006] in the studies conducted in the lower section of the Smortawa river. The authors report $\mathrm{BOD}_{5}$ value in a range of 1.5 to $8.1 \mathrm{mg} \cdot \mathrm{dm}^{-3}$.

Due to $\mathrm{BOD}_{5}$ load values (Table 2) the studied river can be divided into two parts. The first includes agricultural areas, where there are least settlement units. That area is located from Krynica to Zasady, where the load of $\mathrm{BOD}_{5}$ was small and underwent minor changes along the watercourse on this section (from 1.35 to $7.57 \mathrm{~g} \mathrm{O}_{2} \cdot \mathrm{s}^{-1}$ ). These areas are covered largely by Knyszyńska Forest, which may help to reduce the migration of organic substances [Skorbiłowicz 2004 Piekutin 2008]. Forest should be regarded as geochemical barrier. The second part of the basin characterized by a much larger loads of $\mathrm{BOD}_{5}$ and belong to the more urbanized areas. At points located from Suprasl to Dzikie, the main watercourse passes through more settlement units and peaty areas, hence the charges of $\mathrm{BOD}_{5}$ for this area were higher and ranged from 32.45 to $46.95 \mathrm{~g} \mathrm{O}_{2} \cdot \mathrm{s}^{-1}$.

Changes in concentration of $\mathrm{N}-\mathrm{NH}_{4}{ }^{+}$in Supraśl waters were similar to changes which chlorides were subject to (Table 1). Just as in the case of $\mathrm{Cl}$ maximum concentration of $\mathrm{N}-\mathrm{NH}_{4}^{+}$was observed in waters around Gródek and Dzikie and were equal 0.58 and $0.59 \mathrm{mg} \cdot \mathrm{dm}^{-3}$ respectively. A common maxima of these components suggest a common source, which in this case may be sewage treatment plants. In other points the concentration

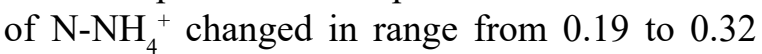
$\mathrm{mg} \cdot \mathrm{dm}^{-3}$. Chomutowska and Wilamowski [2014] received a similar range of $\mathrm{N}-\mathrm{NH}_{4}{ }^{+}$in studies carried out in Łutownia river waters flowing through the Białowiska Forest. The authors recorded results within the range from 0.36 to $0.70 \mathrm{mg} \cdot \mathrm{dm}^{-3}$.

The largest load of ammonium nitrogen (6.16 g N-NH $\left.{ }_{4} \cdot \mathrm{s}^{-1}\right)$ occurred in water collected at point Dzikie, which was associated with the loads of components carried with the Biała, which flows into the Supraśl near that point (Table 2). The smallest load $\left(0.07 \mathrm{~N}-\mathrm{NH}_{4} \cdot \mathrm{s}^{-1}\right)$ was observed in water collected in Krynica, which is due to the absence of significant sources of organic matter at this point. The spatial distribution loads of $\mathrm{N}-\mathrm{NH}_{4}{ }^{+}$and $\mathrm{BOD}_{5}$ loads may indicate a common source of these nutrients in the Supraśl basin.

$\mathrm{SO}_{4}^{2-}$ concentration in the studied rivers did not show a large variation, which is confirmed by approximate arithmetic mean and median, and a low standard deviation (Table 1). $\mathrm{SO}_{4}{ }^{2-}$ varied from 27.96 to $38.37 \mathrm{mg} \cdot \mathrm{dm}^{-3}$. The lowest concentration of $\mathrm{SO}_{4}{ }^{2-}$ was observed in water near 
Supraśl and the largest near Dobrzyniewo. The observed concentrations of $\mathrm{SO}_{4}{ }^{2-}$ are among the values found in uncontaminated waters.

The lowest load of $\mathrm{SO}_{4}^{2-}\left(8.24 \mathrm{~g} \cdot \mathrm{s}^{-1}\right)$ was observed in water taken from point Krynica (Table 2). An upward trend of $\mathrm{SO}_{4}^{2-}$ load along the river was observed, which was related to the gradual seminatural enrichment of Supraśl waters in $\mathrm{SO}_{4}{ }^{2-}$ as a result of runoff from its catchment area and from anthropogenic sources. A significant reduction in load of $\mathrm{SO}_{4}^{2-}$ in waters collected from Dobrzyniewo was reported. Arithmetic mean and median of $\mathrm{SO}_{4}^{2-}$ loads was equal to respectively $128.54 \mathrm{~g} \mathrm{SO}_{4}^{2-\cdot} \mathrm{s}^{-1}$ and $70.20 \mathrm{~g} \mathrm{SO}_{4}^{2-\cdot} \mathrm{s}^{-1}$. Changes of $\mathrm{SO}_{4}{ }^{2-}$ loads along the river were similar to $\mathrm{Cl}^{-}$changes, which may indicate a common origin of these components.

$\mathrm{PO}_{4}^{3-}$ concentration in water of the Supraśl river varied (Table 1). The largest concentration of $\mathrm{PO}_{4}^{3-}$ recorded in waters near Grodek and Dzikie, which were respectively 5.35 and 1.43 $\mathrm{mg} \cdot \mathrm{dm}^{-3}$. The reason for increased $\mathrm{PO}_{4}{ }^{3-}$ concentration may be discharges from the wastewater treatment plant adjacent to water sampling sites. In remaining control points $\mathrm{PO}_{4}^{3-}$ concentration was aligned and varied from 0.50 to $0.89 \mathrm{mg}^{\cdot} \mathrm{dm}^{-3}$. Lower $\mathrm{PO}_{4}^{3-}$ concentration within the range from 0.038 to $0.59 \mathrm{PO}_{4}^{3-}$ were shown by Wiatkowski [2010] in water flowing into Psurów reservoir.

The lowest phosphates load $\left(0.15 \mathrm{~g} \mathrm{PO}_{4}^{3-\cdot} \cdot \mathrm{s}^{-1}\right)$ was observed in water taken from Krynica (Table 2). The largest load was achieved in Dzikie $\left(13.86 \mathrm{~g} \mathrm{PO}_{4}^{3-\cdot} \cdot \mathrm{s}^{-1}\right)$, so that the difference between the largest and smallest load was very high, which could be related to the discharge of inadequately treated sewage from the plants located in the Supraśl basin [Skorbiłowicz 2004 Piekutin 2008]. The presence of large differences between loads values were confirmed by standard deviation values equal to $4.37 \mathrm{~g} \mathrm{PO}_{4}^{3-\cdot} \cdot \mathrm{s}^{-1}$.

Comparing the concentrations of each component with numbers falling within the limits from
Table 2. Loads summary (arithmetic mean) of tested indicators in the Supraśl river waters in 2014

\begin{tabular}{|l|c|c|c|c|c|}
\hline \multirow{2}{*}{ Localization } & $\mathrm{Cl}^{-}$ & $\mathrm{BZT}_{5}$ & $\mathrm{~N}^{-\mathrm{NH}_{4}}{ }^{+}$ & $\mathrm{SO}_{4}{ }^{2-}$ & $\mathrm{PO}_{4}{ }^{3-}$ \\
\cline { 2 - 6 } & \multicolumn{5}{|c|}{$\left[\mathrm{g} \cdot \mathrm{s}^{-1}\right]$} \\
\hline Krynica & 1.65 & 1.35 & 0.07 & 8.24 & 0.15 \\
\hline Gródek & 4.52 & 7.86 & 0.42 & 24.08 & 3.98 \\
\hline Nowosiółki & 8.29 & 5.14 & 0.45 & 52.35 & 1.08 \\
\hline Zasady & 21.55 & 7.57 & 0.53 & 77.15 & 1.33 \\
\hline Supraśl & 40.95 & 46.95 & 1.36 & 192.26 & 3.64 \\
\hline Nowodworce & 38.49 & 32.45 & 1.53 & 247.27 & 3.87 \\
\hline Dobrzyniewo & 13.29 & 8.13 & 0.44 & 63.25 & 1.43 \\
\hline Dzikie & 95.29 & 37.26 & 6.16 & 363.73 & 13.86 \\
\hline Arithmetic mean & 27.94 & 18.34 & 1.37 & 128.54 & 3.67 \\
\hline Median & 17.41 & 7.99 & 0.49 & 70.20 & 2.53 \\
\hline Standard deviation & 30.90 & 17.60 & 2.00 & 126.24 & 4.37 \\
\hline Minimum & 1.65 & 1.35 & 0.07 & 8.24 & 0.15 \\
\hline Maximum & 95.29 & 46.95 & 6.16 & 363.73 & 13.86 \\
\hline
\end{tabular}

Regulation of the Minister of Environment of 22 October 2014, it was found that $\mathrm{pH}$, conductivity, dissolved oxygen, $\mathrm{Cl}^{-}, \mathrm{N}_{-} \mathrm{NH}_{4}^{+}$and $\mathrm{SO}_{4}{ }^{2-}$ allows for the classification of waters Supraśl to first-class quality. Because of the $\mathrm{BOD}_{5}$ value the Supraśl can be classified as second class quality and due to the concentration of $\mathrm{PO}_{4}^{3-}$ the studied river water can be defined as non-classified.

In the variables set statistically significant correlations were observed at the level of $\alpha=0.05$ between $\mathrm{pH}$ and $\mathrm{PO}_{4}{ }^{3-}$ load (Table 3). That link it belonged to a group of moderate negative correlation (-0.38). In terms of increasing $\mathrm{pH}$ the amount of dissolved phosphates in water decreases. The result of that process can be gradual accumulation of phosphorus in bottom sediments. It was also observed relationship between $\mathrm{Cl}^{-}$and $\mathrm{SO}_{4}{ }^{2-}$ load and conductivity. Value of this relationship was positive and for the individual components was equal 0.27 and 0.28 respectively. The link in the case of $\mathrm{Cl}^{-}$and $\mathrm{SO}_{4}^{2-}$ can be explained as a param-

Table 3. Pearson correlations between variables adopted for analysis

\begin{tabular}{|c|c|c|c|c|c|c|c|c|}
\hline Loads & $\mathrm{pH}$ & Conductivity & $\mathrm{O}_{2}$ & $\mathrm{Cl}$ & $\mathrm{BZT}_{5}$ & ${\mathrm{~N}-\mathrm{NH}_{4}}^{-}$ & $\mathrm{SO}_{4}{ }^{2-}$ & $\mathrm{PO}_{4}{ }^{3-}$ \\
\hline Odczyn & 1.00 & -0.20 & -0.03 & 0.14 & -0.05 & 0.16 & 0.04 & $-\mathbf{0 . 3 8}$ \\
\hline Przewodność & -0.20 & 1.00 & 0.02 & $\mathbf{0 . 2 7}$ & -0.06 & 0.38 & $\mathbf{0 . 2 8}$ & 0.15 \\
\hline $\mathrm{O}_{2}$ & -0.03 & 0.02 & 1.00 & -0.14 & 0.03 & 0.11 & 0.13 & 0.22 \\
\hline $\mathrm{Cl}^{-}$ & 0.14 & $\mathbf{0 . 2 7}$ & -0.14 & 1.00 & -0.01 & 0.20 & $\mathbf{0 . 3 8}$ & -0.01 \\
\hline $\mathrm{BZT}_{5}$ & -0.05 & -0.06 & 0.03 & -0.01 & 1.00 & $\mathbf{0 . 4 3}$ & $\mathbf{0 . 4 9}$ & 0.09 \\
\hline${\mathrm{N}-\mathrm{NH}_{4}}^{\mathrm{SO}_{4}{ }^{2-}}$ & 0.16 & $\mathbf{0 . 3 8}$ & 0.11 & 0.20 & $\mathbf{0 . 4 3}$ & 1.00 & $\mathbf{0 . 7 3}$ & 0.03 \\
\hline $\mathrm{PO}_{4}{ }^{3-}$ & 0.04 & $\mathbf{0 . 2 8}$ & 0.13 & $\mathbf{0 . 3 8}$ & $\mathbf{0 . 4 9}$ & $\mathbf{0 . 7 3}$ & 1.00 & 0.23 \\
\hline
\end{tabular}


eter describing the relation of bulk salinity and its individual components. $\mathrm{BOD}_{5}$ load was linked with $\mathrm{N}-\mathrm{NH}_{4}{ }^{+}$and $\mathrm{SO}_{4}{ }^{2-}$ loads. This link is in both cases was positive and amounted to 0.43 and 0.49 respectively. This relation may indicate a common source of these nutrients which are treated wastewater discharged by treatment plants located in the Supraśl basin.

\section{CONCLUSIONS}

1. Supraśl waters, due to the values of most analyzed parameters, should be classified as first quality class.

2. The source of $\mathrm{Cl}^{-}, \mathrm{SO}_{4}{ }^{2-}, \mathrm{N}_{-} \mathrm{NH}_{4}{ }^{+}$in the Supraśl waters were treated wastewater and other anthropogenic sources associated with catchment development.

3. Reduced Supraśl water quality is caused by the inflow of organic substances expressed by $\mathrm{BOD}_{5}$ of natural and anthropogenic origin and concentration of $\mathrm{PO}_{4}^{3-}$, whose main source was treated wastewater.

4. It was shown that correlations between the loads of $\mathrm{BOD}_{5}, \mathrm{~N}^{-\mathrm{NH}_{4}^{+}}$and $\mathrm{SO}_{4}^{2-}$ may be related to a common origin source of those ingredients in the Supraśl waters. Concentration and loads distribution of these parameters along the river also points to their common origins which are treated wastewater located in the catchment area.

\section{REFERENCES}

1. Allan J.D. 1998. Ekologia wód płynących. Wydawnictwo Naukowe PWN, Warszawa.

2. Augustyn Ł., Kaniuczak J., Stanek-Tarkowska J. 2011. Wybrane właściwości fizykochemiczne i chemiczne wód powierzchniowych Wisłoki przeznaczonych do spożycia. Inżynieria Ekologiczna, 28, 7-19.

3. Bajkiewicz-Grabowska E., Mikulski Z. 2010. Hydrologia ogólna. Wydawnictwo naukowe PWN, Warszawa.

4. Brykała D. 2009. Przestrzenne i czasowe zróżnicowanie odpływu rzecznego w dorzeczu Skrwy Lewej, PAN IGiPZ, Warszawa.

5. Chomutowska H., Wilamowski K. 2014. Analiza czystości wód rzeki Łutowia na terenie Puszczy Białowieskiej. Inżynieria Ekologiczna, 38, 117-128.

6. Duffy S.J., VanLoon G.W. 2008. Chemia środowiska. Wydawnictwo Naukowe PWN, Warszawa.

7. Kiryluk A., Skorbiłowicz M. 2005. Wpływ mineralizacji gleb pobagiennych na jakość wód rzeki
Supraśl. Inżynieria Ekologiczna, nr 13.

8. Kociołek-Balawejder E., Stanisławska E. 2012. Chemia środowiska. Wydawnictwo Uniwersytetu Ekonomicznego we Wrocławiu, Wrocław.

9. Krzemińska A., Andrykiewicz-Piragas M., Kazimierska R. 2006. Ocena warunków tlenowych dolnego odcinak rzeki Smortawy jak podstawa oceny samooczyszczania się wód w świetle Ramowej Dyrektywy Wodnej. Infrastruktura i Ekologia Terenów Wiejskich, 4/3, 67-76.

10. Osmulska-Mróz B., Borzyszkowski J., Rąkowski G. 1993. Program ochrony środowiska i sanitacji gminy Wasilków. Instytut Ochrony Środowiska, Warszawa.

11. Piekutin J. 2008. Ocena zanieczyszczenia płynących wód powierzchniowych na terenie powiatu białostockiego. Ochrona Środowiska i Zasobów Naturalnych, nr 35/35.

12. Program gospodarczo-ochronny leśnego kompleksu promocyjnego „Puszcza Knyszyńska”, 2013. Regionalna Dyrekcja Lasów Państwowych w Białymstoku, Białystok.

13. Ptoszek B. 2008. Zagrożenie wód powierzchniowych związkami humusowymi w zlewniach lesistych i zatorfionych na przykładzie rzeki Supraśl. Ochrona Środowiska i Zasobów Naturalnych, nr 35/36.

14. Ptoszek B. 2014. Wybrane problemy gospodarowania zasobami wodnymi obszaru Puszczy Knyszyńskiej. Stowarzyszenie Uroczysko, Supraśl.

15. Rozporządzenie Ministra Środowiska z dnia 22 października 2014 roku, w sprawie klasyfikacji jednolitych części wód powierzchniowych.

16. Skorbiłowicz M. 2004. Wpływ rodzaju zlewni na stężenie wybranych makroskładników w wodach górnej Narwi. Woda Środ. Obsz. Wiej. 4, 1(10), 117-123.

17. Skorbiłowicz M. 2010. Czynniki i procesy kształtujące obieg składników mineralnych w wodach rzecznych zlewni górnej Narwi. Oficyna Wydawcza Politechniki Białostockiej, Białystok.

18. Skorbiłowicz M., Ofman P. 2014. Seasonal changes of nitrogen and phosphorus concentration in Supraśl river. Journal of Ecological Engineering, 15(1), 26-31.

19. Skorbiłowicz M., Skorbiłowicz E., Dzienis L. 2003. Oddziaływanie oczyszczalni ścieków na chemizm wód wybranych rzek zlewni górnej Narwi. Zeszyty Naukowe Politechniki Białostockiej. Inżynieria Środowiska, Oficyna Wydawcza Politechniki Białostockiej, Białystok.

20. Sojka M. 2009. Ocena ładunków związków biogennych wymywanych ze zlewni cieku Dębina. Pomorskie Towarzystwo Naukowe Ochrony Środowiska, 11, 1225-1234.

21. Wiatkowski M. 2010. Zmiany wbranych wskaźników jakości wody rzeki Prosny przepływającej przez zbiornik Psurów. Proceedings of ECOpole, 4(2), 495-500.

22. www.geomelio.pl 